\title{
ANALISIS DAMPAK KONVERSI MINYAK TANAH KE GAS ELPIJI TERHADAP PENINGKATAN PENDAPATAN INDUSTRI BAGEA DI KOTA PALOPO
}

\author{
KARLINA MASKUR, NURSAN, I KETUT PATRA
}

\begin{abstract}
ABSTRAK
Penilaian perbandingan pendapatan pengusaha kue bagea yang menggunakan bahan bakar minyak tanah dengan yang menggunakan bahan bakar gas elpiji pada tabel-tabel tersebut.maka penulis menyimpulkan bahwa, dengan menggunakan bahan bakar gas elpiji lebih menguntungkan karena pendapatannya lebih besar dibandingkan dengan yang menggunakan bahan bakar minyak tanah.

Penelitian ini bertujuan untuk mengetahui dan menganalisa Apakah Dampak Konversi Minyak Tanah ke Gas Elpiji Berpengaruh Terhadap peningkatan pendapatan usaha industri Bagea di Kota Palopo.

Berdasarkan hasil penelitian diharapkan dapat mendorong terwujudnya sektor ekonomi yang semakin seimbang dan kokoh yakni antara sektor industri yang maju dengan adanya kebijakan pemerintah mengenai konversi minyak tanah ke gas elpiji khususnya pada industri bagea.

Kesimpulannya bahwa dalam menggunakan bahan bakar gas elpiji lebih menguntungkan atau lebih efesien di bandingkan dengan menggunakan bahan bakar minyak tanah dalam memproduksi kue bagea.
\end{abstract}

Kata kunci: konversi minyak tanah, gas elpiji, pendapatan, industri bagea 


\section{Pendahuluan}

\section{Latar Belakang}

Sebagian besar industri di Indonesia terutama industri menengah ke bawah menggunakan minyak tanah sebagai bahan bakar untuk memproduksi.Namun akhirakhir ini minyak tanah menjadi sulit didapatkan dan kalaupun ada harganya juga relative mahal, sehingga banyak industri menjadi kesulitan untuk memperolehnya, kelangkaan dan mahalnya harga minyak tanah ini terjadi karena adanya pengurangan supply dan pengurangan subsidi pada minyak tanah sehubungan dengan adanya kebijakan pemerintah tentang Program Konversi Minyak Tanah ke Gas LPG (Elpiji).

Aktivitas ekonomi juga terjadi dalam jalur distribusi LPG sejak dari lapangan produksi ataupun impor hingga konsumen. Selain berupa pembangunan infrastruktur,termasuk kapal pengangkut,juga memacu investasi bidang pengangkutan,stasiun pengisian,penyaluran dan pemeliharaan SPBE,rantai usaha juga membuka peluang usaha berupa pembukaan agen, Sub Agen dan Pangkalan/Penyalur. Bahkan saat ini, di jalur paling ujung sebelum konsumen juga berkembang usaha penjualan LPG $3 \mathrm{Kg}$ eceran.baik oleh toko kelontong maupun pedagang keliling yang sebelumnya menjajakan Minyak Tanah, berapapun kegiatan ini telah menjadi nilai tambah ekonomi dalam rantai penyaluran LPG $3 \mathrm{Kg}$.

Melihat keadaan tersebut maka LPG (Elpiji) pantas di pilih karena produksi dan potensi kandungannya masih cukup besar di indonesia. Untuk konsumsi domestic sudah lebih dari cukup sehingga sebagian masih bisa di Ekspor dari segi ini,berdasarkan kesetaraan nilai kalori,subsidi LPG (elipiji) lebih rendah dari pada minyak tanah.Pemerintah dapat menghemat subsidi sehingga Rp.15- Rp.20 Triliun jika program ini berhasil.

Melihat kelebihan dan kekurangan dari penggunaaan Gas LPG tersebut maka industri-industri khususnya industri yang memproduksi Bagea mau tak mau harus beralih ke pengguanaan Gas LPG yang pada akhirnya member pengaruh terhadap pertumbuhan ekonomi pada industri Bagea yang ada di Kota Palopo.dengan melihat fenomena yang terjadi dengan uraian di atas maka peneliti bermaksud mengadakan sebuah penelitian dengan mengangkat judul "Analisis Dampak Konversi Minyak Tanah ke Gas Elpiji Terhadap Peningkatan Pendapatan Industri Bagea di Kota Palopo.

Berdasarkan hal tersebut, maka rumusan masalah penelitian ini adalah: Seberapa Besar Dampak Konversi Minyak Tanah ke Gas Elpiji Berpengaruh Terhadap Peningkatan Pendapatan Usaha Industri Bagea di Kota Palopo. Tujuan penelitian ini adalah untuk mengetahui dan menganalisa Apakah Dampak Konversi Minyak Tanah ke Gas Elpiji Berpengaruh Terhadap peningkatan pendapatan usaha industri Bagea di Kota Palopo. 


\section{Metode Penelitian}

\section{Tempat dan Waktu Penelitian}

Dalam melaksanakan kegiatan penelitian ini penulis memilih objek penelitian pada industri-industri Bagea di Kota Palopo dalam waktu yang direncanakan selama 2 (dua) bulan.

\section{Jenis dan Sumber Data}

Jenis dan sumber data yang di gunakan dalam penyusunan penelitian ini adalah sebagai berikut :

1. Data Primer yaitu data yang diperoleh langsung melalui penelitian lapangan atau pengamatan langsung, wawancara langsung dengan pimpinan dan staf karyawan, maupun observasi langsung terhadap sumber data yang di butuhkan.

2. Data Sekunder yaitu data yang di peroleh melalui buku-buku literature atau buku bacaan lainnya diperpustakaan seperti tulisan-tulisan ilmiah, teori-teori, diklat-diklat dan hasil-hasil penelitian campuran yang dipergunakan dalam penulisan ini.

\section{Populasi dan Sampel}

Populasi dalam penelitian ini adalah seluruh industri Bagea yang ada di Kota palopo yang formal sebanyak 4 (empat) industri Bagea dan non formal sebanyak 4 (empat) industri Bagea, sedangkan yang dijadikan sampel adalah yang formal sebanyak 3 (tiga) Industri Bagea di Kota Palopo.

\section{Metode Pengumpulan Data}

Untuk memperoleh data sebagai berikut penunjang dalam penulisan skripsi, maka penulis mengadakan beberapa metode pengumpulan data sebagai berikut :

a. Penelitian Lapangan ( Field Research ) yaitu, penelitian yang dilakukan dengan jalan pengamatan langsung ke lapangan atau objek dengan cara mengadakan wawancara ( interview ) dengan pimpinan atau staf karyawan.

b. Penelitian Kepustakaan ( Library research) yaitu penelitian yang di lakukan dengan cara mencari referensi yang berupa buku-buku, majalah, surat kabar, buku-buku lain yang ada hubungannya dengan masalah yang di bahas serta mengumpulkan data yang telah didokumentasikan oleh instansi atau dinas ( yang relevan dengan penelitian ).

\section{Metode Analisis data}

Metode analisis yang digunakan dalam penelitian ini adalah Analisis Komparatif (Perbandingan), dalam hal ini untuk mengetahui berapa besar pendapatan yang dihasilkan industri Bagea di kota palopo dengan menggunakan minyak tanah di bandingkan dengan menggunakan Gas Elpiji. 


\section{Hasil Penelitian Dan Pembahasan}

\section{Deskripsi Hasil Penelitian}

Perkembangan sektor industri diharapkan dapat mendorong terwujudnya sector ekonomi yang semakin seimbang dan kokoh yakni antara sector industry yang maju dengan adanya kebijakan pemerintah mengenai konversi minyak tanah ke gas elpiji khususnya pada industry bagea.

Proses industrialisasi harus mampu mendorong berkembangnya industry sebagai penggerak utama peningkatan laju pertumbuhan ekonomi dan perluasan lapangan kerja. Hal ini menunjukkan bahwa industry memegang peranan penting dalam upaya peningkatan pendapatan dan taraf hidup masyarakat ekonomi lemah.

Untuk memberikan dampak yang nyata dan memaksimalkan pengembangan industry kecil terhadap perubahan struktur ekonomi yang seimbang, maka kebijaksanaan yang akan ditempuh ditujukan kepada usaha untuk meningkatkan pertumbuhan ekonomi selalu dikaitkan dengan peningkatan jalinan antara sector industry dengan sector-sektor lainnya.

Industri kecil dan industri menengah termasuk industri kerajinan dan industri rumah tangga perlu lebih di bina dan untuk menjadi usaha yang semakin efesien dan mampu berkembang mandiri, dan makin mampu meningkatkan peranannya dalam menyediakan lapangan kerja, penyediaan barang dan jasa serta berbagai komponen lainnya baik untuk keperluan pasar dalam negeri maupun pasar luar negeri.

Pada dasarnya kelompok industry kecil, mengingat kemampuannya yang terlampau tinggi dalam mengakomodasi beragam aspek modernitas. Dan sesungguhnya hanya atas skala penyerapan tenaga kerja semata maka kelompok ini menjadi termasuk kedalam bagian subsector industry kecil.

\section{Analisis dan Pembahasan}

Usaha industri Kue Bagea yang ada di kota palopo menggunakan bahan bakar Gas Elpiji terhitung mulai tahun 2010 sampai sekarang yang sebelumnya menggunakan bahan bakar minyak tanah, dengan beralihnya sebagian besar industry bagea menggunakan Gas Elpiji sebagai bahan bakar dapat dilihat perubahan yang signifikan, terutama yang berkaitan dengan keuntungan-keuntungan yang diperoleh oleh setiap industri bagea di kota palopo, karena harga gas elpiji jauh lebih murah dibandingkan dengan harga minyak tanah, hal tersebut dapat dilihat pada peningkatan pendapatan yang diperoleh oleh hampir setiap industri bagea yang ada di kota palopo.

Kue Bagea yang menggunakan Sagu sebagai salah satu bahan bakunya mempunyai cita rasa dan aroma khas mempunyai peluang pasar seperti halnya jenis kue bagea yang lain.dengan cita rasa yang khas tersebut diharapkan akan mempunyai pasaran yang luas baik untuk pasaran lokal maupun antar daerah dan tidak menutup kemungkinan jelas komoditi kue bagea ini dapat menembus pasar internasional. 
Untuk itu mutu pada produksi kue bagea yang meliputi daya tahan, cita rasa, serta kemasan harus lebih ditingkatkan untuk memenuhi selera konsumen.

Untuk mengetahui perbandingan antara pemakaian bahan bakar minyak tanah dan gas elpiji dalam meningkatkan pendapatan para pengusaha industri kue bagea di kota palopo, maka dapat dilihat pada table berikut ini :

\section{Pendapatan Industri Bagea Menggunakan Minyak Tanah}

\begin{tabular}{|c|c|c|c|}
\hline /Semester & $\begin{array}{c}\text { Minyak Tanah } \\
\text { (Rp.000) }\end{array}$ & $\begin{array}{c}\text { Jumlah } \\
\text { Pendapatan } \\
\text { Industri Bagea } \\
\text { (Rp.000) }\end{array}$ & $\begin{array}{c}\text { Perkembangan } \\
\text { Pendapatan ( \% ) }\end{array}$ \\
\hline 2007 ( II ) & 28.000 & 33.900 & 3,83 \\
2008 ( I ) & 29.900 & 35.200 & 4,26 \\
2008 ( II ) & 31.500 & 36.700 & 3,81 \\
2009 ( I ) & 33.500 & 38.100 & 4,19 \\
2009 ( II ) & 36.000 & 39.700 & \\
\hline
\end{tabular}

Sumber : industri kue bagea

Dari table diatas dapat dilihat bahwa pada perkembangan pendapatan industry bagea tahun 2007 semester (II) ke tahun 2008 semester (I) sebanyak 3,38\%, tahun 2008 semester (I) ke semester (II) sebanyak 4,26\% tahun 2008 semester (II) ke tahun 2009 semester (I) sebanyak 3,81\%, tahun 2009 semester (I) ke semester (II) tahun 2009 sebanyak 4,19\%.

Untuk mengetahui perkembangan pendapatan pengusaha Bagea dengan menggunakan gas elpiji dapata dilihat pada tabel berikut :

Pendapatan Industri Bagea Menggunakan Gas Elpiji

\begin{tabular}{|c|c|c|c|}
\hline /Semester & Konversi & $\begin{array}{c}\text { Jumlah } \\
\text { Pendapatan } \\
\text { Industri Bagea } \\
\text { (Rp.000) }\end{array}$ & $\begin{array}{c}\text { Perkembangan } \\
\text { Pendapatan }\end{array}$ \\
\hline 2010 (I) & 53.500 & 65.000 & 4,61 \\
2010 (II) & 55.000 & 68.000 & 6,17 \\
2011 (I) & 58.000 & 72.200 & 6,64 \\
2011 (II) & 62.500 & 77.000 & 12,98 \\
2012 (I) & 66.000 & 87.000 & \\
\hline
\end{tabular}

Sumber : Industri Kue Bagea

Dari tabel di atas dapat dilihat bahwa perkembangan pendapata Industri kue Bagea tahun 2010 semester (I) ke semester (II) sebanyak 4,61\%, tahun 2010 semester (II) ke tahun 2011 semester (I) sebanyak 6,17\% tahun 2011 semester (I) ke 
semester (II) meningkat menjadi 6,64\% tahun 2011 semester (II) ke tahun 2012 semester (I) mencapai 12,98\%.

Dari perbandingan pendapatan menggunakan bahan bakar gas elpiji lebih menguntungkan dari pada menggunakan bahan bakar minyak tanah.

Dengan melihat perbandingan pendapatan pengusaha kue bagea yang menggunakan bahan bakar minyak tanah dengan yang menggunakan bahan bakar gas elpiji pada tabel-tabel diatas.maka penulis menyimpulkan bahwa, dengan menggunakan bahan bakar gas elpiji lebih menguntungkan karena pendapatannya lebih besar dibandingkan dengan yang menggunakan bahan bakar minyak tanah.

\section{Penutup}

\section{Simpulan}

Berdasarkan pembahasan hasil penelitian, maka dapat ditarik kesimpulan bahwa dalam menggunakan bahan bakar gas elpiji lebih menguntungkan atau lebih efesien di bandingkan dengan menggunakan bahan bakar minyak tanah dalam memproduksi kue bagea.

\section{Saran}

Dari simpulan di atas sebagai hasil analisis komparatif dari berbagai data dan informasi maka penulis menyarankan :

a. Bagi pengusaha kue bagea seyogyanya menggunakan bahan bakar Gas Elpiji karena pendapatannya meningkat dimana gas elpiji lebih murah.

b. Bagi pemerintah agar supaya lebih memperlihatkan pengusaha kue bagea dalam hal ini mempermudah penggusuran surat izin usaha industry dan memberikan bantuan-bantuan berupa alat-alat dalam produksi kue bagea.

\section{Daftar Pustaka}

Anonym, Surat Menteri Dalam Negeri, 2007. Tentang Pelaksanaan Konversi Minyak Tanah ke LPG $3 \mathrm{Kg}$. Jakarta.

Peraturan Menteri Dalam Negeri. Tentang Dukungan Pelaksanaan Konversi Minyak Tanah ke LPG 3 Kg. Nomor 42 Tahun 2010. Jakarta.

Peraturan Walikota Palopo. Tentang Penetapan Harga Eceran Tertinggi.2011. Palopo.

Konversi Minyak Tanah ke Gas LPG , Jurnal Ilmiah, (online), (http://www.artikelkita.com, di akses 22 nopember 2011).

Analisis Komparatif, Jurnal Ilmiah, (online), (http://www.artikelkita.com, di akses 04 juni 2012). 
Donal R. Cooper. 2006. Metode Riset Bisnis. Jakarta. PT Media Global Edukasi.

Kementerian industry R.I. Tahun 2010 - 2014, Revitalisasi dan Penumbuhan IKM Wilayah III.

Louis E. Boone dan David L. Kurtz 2002. Pengantar Bisnis. Jilid II. Jakarta Erlangga.

Muhammad. 2008. Metodologi Penelitian Ekonomi Islam, Pendekatan Kuantitatif. Jakarta. Rajawali.

Nuraini Ida, 2001. Pengantar Ekonomi Mikro, Penerbit Universitas Muhammadiyah Malang.

Ridwan. 2003. Dasar - dasar Statistik. Jakarta. Alfabeta

Sugiarto, dkk, 2005, Ekonomi Mikro ; Sebuah Kajian Komprehensif, Jakarta, PT. Gramedia Pustaka Utama.

Sukirno, Sadono, 2007, Ekonomi Pembangunan : Proses, Masalah, dan Dasar Kebijakan, Jakarta, Kencana.

Teguh. Muhammad. 2010. Ekonomi Industri. Jakarta. Rajawali Pers. 